\title{
Tourism, vulnerability, and economic crisis within APEC: responses from international destinations - Phuket, Thailand and Los Cabos, Mexico
}

\author{
A. Gámez ${ }^{1}$, A. Ivanova $^{1} \&$ K. Campiranon ${ }^{2}$ \\ ${ }^{1}$ Department of Economics, \\ Universidad Autónoma de Baja California Sur, Mexico \\ ${ }^{2}$ DPU International College, Dhurakij Pundit University, Thailand
}

\begin{abstract}
The Subprime Crisis in 2008 showed the need to devise mechanisms of economic adaptation and prevention of losses in a context of extreme vulnerability, which defied traditional views of economic and political organization worldwide. For the tourism sector the challenge doubled since it is normally highly vulnerable to external impacts, which in turn tend to compromise the capacity of recovery of tourist destinations. This paper offers a comparison of responses from the lodging sector to the world economic crisis in two APEC tourism destinations: Phuket (Thailand) and Los Cabos (Mexico). Both destinations reflect a dynamic model of foreign investment and demand and are site to processes of economic and demographic growth that foster controversial local and external interactions. An analysis of perceptions and actions taken by the hotel sector to face the still undergoing economic crisis could help strengthen the sector's capacity of recovery so that lessons can be advanced for the future and other similar destinations.
\end{abstract}

Keywords: international crisis, tourism vulnerability, APEC, Los Cabos, Phuket.

\section{Introduction}

Although the importance of tourism for recovery has been acknowledged both internationally and at the national level in the context of one of the most acute economic crisis of the last century, there is a scarcity of studies which focus on 
how tourist destinations faced the crisis. Understanding how the industry coped during the economic crisis is crucial not only for academic purposes but also to provide managerial implications to tourism suppliers so that they can come up with an effective marketing strategy which can be applied in other economic crisis situations.

This paper refers to Phuket (Thailand) and Los Cabos (in Mexico's northwestern peninsula) as examples of a luxury-type of international seaside destination, which target foreign markets and is thus more vulnerable to international shocks. Both cases represent the integration of once remote areas to the international tourism market, what has been welcomed given the opportunities for economic returns, the potential for regional development, and the array of positive interrelations that tourism fosters. However, as in many other cases (Müller and Jansson [1]), those regions share a common pattern that is characterized by the lack of local capital, know-how mechanisms, and control of commercialization chains, especially regarding tourism resorts. This situation has made the sector's growth dependent mainly on foreign investment. As a consequence, the most profitable areas of tourism are externally run and the benefits derived from economic growth tend to follow that same pattern, what. This set of factors can lead to both positive and negative outcomes. In the first case, due to their size and resources, resorts which are part to international nets can better resist shocks; in the second case, profits tend to concentrate abroad and the immediate impacts of the crisis be felt strongly at the local level, as the economy functions around investments from abroad. In this regard, devising mechanisms of crisis prevention and recovery play an important role for both the private sector in terms of loss minimization, and for the public sector as a way to avoid long-term economic stagnation.

The following sections deal with results from a research that was conducted simultaneously in Phuket and Los Cabos in order to assess the effects of the economic crisis on the lodging sector and their responses to countervail them. Understanding the negative factors behind the tourism industry decline and identifying best practices or 'critical success factors' of economic crisis management are crucial to provide an essential foundation for assisting both industry and government bodies to develop strategies to avoid or cope with future crises (Faulkner [2]). In both cases, the study relied on in-depth interviews with high-level executives (e.g. directors, general managers, company advisors, and presidents) at hotels in Los Cabos and Phuket that had already been in business prior to 2008 , when the global economic crisis started.

\section{Tourism and vulnerability in Phuket, Thailand: perceptions of the hotel sector about the crisis}

One of the most popular tourist destinations in Thailand is Phuket. Phuket is Thailand's largest island and is often dubbed as 'the Pearl of the Andaman', or 'the Pearl of the South'. Its natural resources, rocky peninsular, limestone cliffs, white powdery beaches, tranquil broad bays and tropical in-land forests 
contribute to making it the South's wealthiest, busiest, most visited and most popular island and province (Tourism Authority of Thailand [3]).

Like other tourism destinations in Thailand, Phuket has been severely affected by the contraction of long-haul markets (Theparat [4]). Strongly affected by the 2004 tsunami, Phuket's tourist business recovery had been endorsed by The Tourism Authority of Thailand's statistics, but the current global economic crisis, however, sent visitor numbers plunging once again (The Age [5]). This statement has been supported by the Phuket Tourist Association, which stated that the number of tourists coming to the Andaman coast in 2009 fell slightly owing to the current global economic downturn (MCOT [6]).

In turn, the Phuket hotel industry has suffered a blow to key metrics, revenue per available room (RevPAR) and average room rates (ADR). Wide scale discounting of $20 \%$ led to losses in 2009 of approximately US\$300 million in room revenue. In fact, Phuket's annual visitor arrivals of 2.9 million in 2009 are only equivalent to those in 2007 level (C9 Hotelworks [7]). Visitor arrivals at Phuket International Airport during the economic crisis period were significantly lower than the number of visitor arrivals during the same month a year ago. In addition, bottom lines have been hit as hoteliers attempted to induce demand and meet increasing consumer pressure for lower rates. Virtually every chain scale tier was affected with the exception of the budget and economy segment. In summary, 2.9 million tourists visited Phuket in 2009 with an island-wide average occupancy of $64 \%$. This means average rates and revenue per occupied room have dropped by $20 \%$ and $22 \%$ respectively compared to 2008 (C9 Hotelworks [7]).

Clearly, the economic crisis has affected the international tourism demand worldwide, and Phuket is no exception (The Age [5]). Such a crisis has caused a sharp drop in tourist arrivals, and this is likely to be the major reason why the international tourism demand in Phuket has declined recently. As mentioned, hotels with room rates of at least 133 USD per night, which is an average room rate in Phuket (Koldowski [8]), were the target of in-depth interviews with key informants leading to the identification of five critical success factors, as follows: Crisis Management Plan, Crisis Market Segmentation, Crisis Marketing Promotion, Crisis Collaboration, and Crisis Personnel Management.

Crisis Management Plan. The first critical success factor for tourism organizations is to have a crisis management plan in place, which is supported by a number of scholars (Augustine [9]; Faulkner [10]; PATA [11]; Ruff and Aziz [12]; UNWTO [13]). It should be noted, however, that a crisis management plan is only a basic guideline. The plan needs to be adapted to the situation, location, and market. Such findings have been supported by tourism scholars who stated that each crisis requires a different crisis management plan (Aktas and Gunlu [14], Henderson [15]).

Crisis Market Segmentation. Although Phuket has successfully attracted a number of tourists from both overseas and domestic markets in the past, keeping this trend during the economic crisis has become increasingly difficult. For overseas markets, it is vital for the tourism industry in Phuket to focus either on markets that have not been affected, or emerging markets; moreover, Phuket is a 
seasonal destination. Promoting Phuket during the low seasons, six months from May to October, is extremely challenging (Mantanarat [16]). Therefore Phuket's tourism industry would need to match the right market with the right season.

With regard to the domestic market, results support tourism literature which shows that Thai tourists perceive Phuket as a rather expensive destination (Kaenkrachang [17]), which primarily welcomes overseas tourists (Khamlo [18]). Although Phuket can successfully attract domestic tourists, those tourists are likely to spend less than overseas tourists and also tend to stay at lowmedium level hotel accommodation (Thai Websites [19]). Therefore, mediumhigh level hotels in Phuket would need to work harder to attract domestic tourists who could afford their products.

Crisis Marketing Promotion. Tourists are generally cost-conscious during an economic crisis. Hence a marketing promotion offered by tourism organizations needs to explain the possibilities of having an affordable quality holiday. Findings from this research have shown that there are largely two approaches of doing so, either by discounting or by adding value to the tourism products. Both approaches are discussed below.

Adding value to the tourism products appears to be a superior approach for attracting customers during an economic crisis. The Tourism Authority of Thailand (TAT), for example, launched a global campaign 'Amazing Thailand, Amazing Value' in 2009. By emphasizing Thailand's worthwhile proposition, TAT can better address travellers who still like to go on vacation, but to a lesscostly destination. A survey by $\mathrm{CNN}$ has confirmed the campaign effectiveness, titling Thailand as the best value destination in Asia-Pacific (Ketter [20]). In order for the tourism industry in Phuket to maximize product value from a limited marketing budget, effective collaboration with tourism stakeholders is needed.

Crisis Collaboration. A common problem during an economic crisis happens when tourism organizations compete against others by using discounting strategies. It is therefore suggested that tourism organizations work hand-in-hand with suppliers in order to achieve an economy of scale which would lower the total product costs. As Beirman [21] has explained, collaboration among tourism organizations, together with the government's support, would enable them to sell bulk tourism products as an attractive value-added package.

Regarding government's push for crisis collaboration, The Phuket News [22] reported that the Tourism Authority of Thailand (TAT)'s Phuket Office has recently launched a new campaign, encouraging domestic trips to Phuket from Bangkok. The campaign, "Phuket Great Time - Click and Go", is a collective effort from over 100 tourism agencies in Phuket and Phang-nga. Whilst this campaign will only be available to Thai nationals, it is hoped an influx of domestic tourists will be able to compensate for the loss of other tourism markets. Nonetheless, research findings have shown otherwise. Some leading tourism organizations, particularly the TAT and Thai Airways, have been criticized for not doing enough to support the tourism industry during an economic crisis situation. 
Crisis Personnel Management. It should be pointed out that overhead costs amount to the tourism business' biggest challenge. At the same time, employees are the most valuable asset. In turn, tourism organizations in Phuket were cautious with fixed and variable costs during an economic crisis in which generating revenue became difficult. Therefore, it is important to have a personnel management plan that can be implemented and adapted during an economic crisis situation. In fact, the most important thing is that the leader explains clearly why the decision has been made, and how it would help an organization. This is endorsed by Ruff and Aziz [12], who stated that organizations that communicate well internally tend to communicate better overall, achieving more favourable perceptions among external audiences.

On the side of challenges related to climate change, tourism in Thailand is vulnerable insofar as increasing sea temperatures and sea level along the island could lead to a reduction of the coastline and stronger monsoon seasons. Climate change issues and their implications on the tourism industry of Phuket are still to be further debated, but promoting awareness on its significance as threats and opportunities to the economic development of tourism have started (Phuket News [23]).

\section{Tourism and vulnerability in Los Cabos, Mexico: perceptions of the hotel sector about the crisis}

Los Cabos has become the second most important sea-side tourist destination in Mexico. Located in the southernmost tip of the peninsula of Baja California, 1,100 miles away from the border between Mexico and the United States, it used to be a small fishermen town. However, during the last three decades -as a result of a federal government plan to promote seaside resorts in isolated areas- tourism and related activities have shaped not only the area but also the wider economy of the state of Baja California Sur (BCS): about $40 \%$ of the regional economy depends on tourism-related activities, which also directly contributes to about $30 \%$ of the state's employment (Gamez and Angeles [24]). La Paz (the state's capital) has a more diversified economic base, but the significance of tourism in the latter municipality has been on the rise over the last 5-10 years, with a growing orientation towards resort projects over large tracts of the Gulf of California seashore, which typically involve a large number of second homes for mainly American and Canadian citizens, hotels, and golf courses.

In 2008, Los Cabos attracted 1.23 million visitors $(73 \%$ of total tourists in BCS) and was site to $76 \%$ of the state's 18 thousand rooms (most of them in hotels rated 4 or more stars). It is worth noting that the average income of visitors to Los Cabos is US\$77,000; almost doubled that in the rest of the country. Daily spending is estimated at $250-450$ dollars, what explains its preeminence in Mexico's tourism (Gamez and Angeles [24]). Enormous amounts of investment have been made and continue in the region. The origin of investors is mainly foreign and $70 \%$ of direct foreign investment to the state has been directed to La Paz and mostly to Los Cabos. The tourism subsector of hotels and lodging has absorbed most of this investment (Angeles and Gamez [25]). 
In order to assess the degree of vulnerability and adaptability in the tourist lodging sector in Los Cabos, 40 managers in the hotel industry were interviewed. Particularly, we sought to identify the potential attitude and behavioural change with respect to hotel action plans in relation to the current economic crisis as well as natural contingencies. Out of the total, $11 \%$ of the interviews were carried out in the tourist corridor (a 32-kilometres stripe of land were most hotels are located), 28\% in the city of San Jose del Cabo, and 61\% in Cabo San Lucas (the axis of the resort). The selection of the sample was based on the criteria of size and category of the hotel, so that it reflected the hotel structure in the area. Thus, with regard to the first, $25 \%$ of interviews was made in large hotels (with 150 or more rooms); $33 \%$ in medium size hotels (50 to 150 rooms), and $42 \%$ in small hotels (with fewer than 50 rooms). By category, $72 \%$ of the sample was formed by hotels ranging from 3 to 5 stars, being thus representative of the nature of this expensive destination. Interviews related to the perception of signals that the crisis would be so strong; the period and areas of the hotel that felt most the impact of the crisis; effects on employment and purchases to suppliers; current and planned recovery strategies to deal with the crisis; perceptions of recovery; and participatory planning within the company.

The strong impact of the crisis in the hotel (and tourism) sector in Los Cabos was high in 2009. Jobs plummeted especially in the Construction and tourismsupport services sectors, which in turn meant a high level of unemployment (La Jornada [26]. This exposed the high degree of vulnerability of this tourism destination. Among hotels, $83 \%$ declared having noticed early signs that the crisis would be very strong, while only $17 \%$ did not. These signals were mainly related to low occupancy and reservations; to cancellations or room reservations; and, thirdly, to factors such as the opening of new hotels in the area which resulted in more competition in 2009; poor indicators in the economy; staff dismissals and rotation, and the temporary closure of some hotels.

For most, the highest peak phase of the crisis was April 2009, when the United States government warned its citizens not to travel to Mexico due to fear of the spread of the swine flu. However, after that emergency, the economic crisis contributed to the lack of visitors. For almost half of the hotels the summer of 2009 was bad, while a fifth ended the year with serious difficulties. With regard to the operation of hotels, the most affected areas were accommodation $(47 \%)$, while for $25 \%$ of them the most damaged area was food and beverages. This figure shows the magnitude of the affectation, since hotels services rest mainly in those two areas. Only one-tenth of hotels had negative impacts in all areas of its operation.

In spite of experiencing a huge contraction (a loss of 250,000 visitors in 2009 or $25 \%$ of visitors), the reduction of employment in hotels was not an immediate strategy to cope with the crisis. Almost $40 \%$ of hotels did not fire any of its employees and one fifth did so in only $10 \%$. That is, almost $60 \%$ of hotels kept their staff, although this was at the expense of the workers' income as a trade-off to keep their jobs. On the other hand, more than one third reduced their staff between $20-40 \%$. 
On the side of the suppliers, the scene was more dramatic. Almost $40 \%$ of hotels reduced their purchases by half or more; a fifth did so at a rate of between 20-30\%; and only one-tenth did not affect the relationship with its suppliers. This fall in the demand for goods and services had strong implications especially for local suppliers of food and beverages (the most impacted of all), cleaning, maintenance, and entertainment.

Hotels reacted with recovery strategies to the crisis: $60 \%$ of the hotels offered packages, and discounts to visitors; a fifth opted for advertising, followed by agreements with suppliers to reduce costs. By the end of 2010, 64\% had experienced economic recovery, albeit small; whereas the remaining still had not perceived it. The expectation was that a more decisive recovery occurred during winter, when foreign visitors' influx makes up the high season in the region.

Considering the profound impacts of the economic downturn on tourism in Los Cabos, it could be expected that corporations designed and coordinated a plan to prevent or adapt to future emergencies. However, $62 \%$ of respondents considered extreme events (hurricanes, essentially) in its emergency planning, and only a fifth included aspects related to the economic crisis. Most of the hotels have plans to deal with events such as hurricanes and cyclones, as well as fires, and a hotel devised a new program against tsunamis. Measures to be taken in the case of the economic crisis refer to seeking assistance from the public sector, introducing energy-saving programs, negotiating lower prices with suppliers, increasing sales and improving the quality of the service, reducing working hours to avoid worker lay-offs, offering vacation packages, and reducing fixed costs.

The results of the surveys applied to Los Cabos hotel confirm the enormous vulnerability of the destination to changes in perceptions of security, income and nature impacts. During 2009 and 2010, years in which warnings on health security and the first great economic crisis of the developed countries in the second postwar period combine, meant a contraction of the American market, which mostly feeds Los Cabos tourism. Particularly in a region where the hotel sector is the basis of the tourism sector, the drastic decline in room occupation and food and beverage consumption had direct effects in the rest of the local economy through the contraction of demand to suppliers or price negotiations in order to reduce operating costs.

The absence of regional and, in almost half of cases, individual plans to face adverse conditions in the tourism environment is alarming. In this context, the recovery of the sector has been slow and reactive. Several elements can be put forward with regard to the tourism crisis in Los Cabos during 2009-2010. On the one hand, the size of the business seem to have influenced the level of affectation: Los Cabos is a destination where the presence of multinational or national level hotel chains is very high and defines the local hotel supply; thus it can be expected that these companies have sufficient capacity to cope with the decline in visitors. At the other extreme, although the temporary closure of a hotel was reported, small size and family-owned lodging owners were forced to resist since closure would have meant total bankruptcy. In both cases, though, flexible working conditions to preserve jobs were advanced. 
On the other hand, during the last three decades, tourism in Los Cabos has grown at accelerated rates. Possibly this trend has sponsored an atmosphere of bonanza that helps explain the lack of planning even in the case of non-cyclical economic aspects such as water availability. In this regard it is to be noted that, as in the rest of the state, Los Cabos faces a high level of water stress, a resource that is essential to hotel performance (guest use, gardens, and swimming pools). Only half of hotels contemplate planning for contingencies; and slightly less than 2 out of every 10 establishments includes water in them. On the side of environmental certification, only $9 \%$ do, which leaves a wide opportunity margin left to use environmentally friendly strategies as a niche market.

With regard to the effects of climate change, little more than one quarter of the hotels reported affectations. From this, more than half pointed out the extreme weather as the main manifestation of climate change. However, $25 \%$ stressed a rise in discomfort due to hot weather; and $15 \%$ referred to the increase in the intensity and frequency of hurricanes. Only 53\% of the hotels included climate change into its strategies, in the form of electricity and water savings in the first place; a policy of recycling of waste and batteries; separation of trash; and use of solar energy. It is noteworthy that only $9 \%$ of the hotels engage in environmental certification programs, and only $8 \%$ use desalinated water in its operations. This situation shows a low consideration for international trends which posit a high value on the need to reverse environmental impacts of tourism.

\section{Conclusions}

The importance of tourism as an international engine of economic growth is manifested in the enormous amount of resources that derive from the travel and tourist industry worldwide, as shown by indicators such as the services account balances, revenues, job creation, and investment in infrastructure, to mention a few. Policy coordination among governments and cooperation within the private sector extensively exemplify the benefits associated with the industry and also the preoccupation over its deceleration in the context of the current economic and also environmental crisis.

In the light of the above, tourist destinations in developing countries face significant challenges insofar as they tend to depend on foreign capital and the extensive use of local natural resources. Recognizing the vulnerability of tourism destinations which target foreign markets and which are additionally subject to climate change effects due to their seaside location is important in terms of risk prevention and adaptation. Also, given that climate change does not affect all regions equally and not to the same degree, an adaptation plan that effectively coordinates both private and public sectors could seize the opportunities provided by the reorientation of tourist markets towards environmentally friendly tourist projects. As competition among international destinations increases mainly by using price reduction strategies and the sector faces increased costs to provide conditions of comfort for tourists, better training and the consolidation of an image of sustainable use of energy and natural resources management 
could be key elements for the successful continuation of the tourist industry in Los Cabos and Phuket.

Being tourism a sector that is particularly sensitive to climate change, it is pertinent that the private sector understands and is accountable for the effects the tourist industry has on the environment. In this regard, without the existence of schemes of cooperation and action between the private-public sectors it will be difficult to meet short-term contingencies, not to mention structural ones. Establishing criteria of adaptation to changes be those climate-related or of economic nature would allow to deal with vulnerabilities in a comprehensive manner, rather than having fragmented approaches to individual impacts.

Finally, a scheme of both monitoring and information gathering on the crisis' real impacts, on the one hand, and also on the private sector's perceptions to assess the performance of the tourism sector should be established. This would allow to develop more proactive strategies, such as the diversification of tourist markets; take effective steps to improve the level of hotels competitiveness based on product differentiation and higher quality of their services; turn towards environmentally sustainable operation mechanisms; and develop corporate social responsibility, which in addition to be beneficial to workers enhance the tourist image of the region, to name a few. This set of policies could help avoid the decline of hotel rates, and thus the loss of their status as luxurious destinations, what has given them comparative advantage in the international tourism market.

In sum, the current international economic crisis has shown the risks faced by the tourism sector and hotels in particular worldwide, which have serious implications for the rest of the economy. In the context of the little optimistic prospects in the short and medium terms for economic growth in the United States and developed countries generally, markets on which Los Cabos and Phuket depend predominantly, to define schemes of prevention and adaptation is, without doubt, one major challenge.

\section{References}

[1] Müller, D.K. and Jansson, B. Tourism in Peripheries: Perspectives from the Far North and South. Wallingford: CAB International, 2007.

[2] Faulkner, B. Towards a Framework for Tourism Disaster Management. Tourism Management, 22 (2): 135-147, 2001.

[3] Tourism Authority of Thailand. Phuket, February, 2010, http://tourismthailand.org/destination-guide/phuket-83-1-1.html

[4] Theparat, C. Surapong reviews tourism stimulus idea, Bangkok Post, 29th August, 2008, $\quad$ http://www.bangkokpost.com/040808_Business/ 04Aug2008_biz017.php

[5] The Age. Rebirth of Phuket, 2009, http://www.theage.com.au/ travel/accommodation-reviews/rebirth-of-phuket-20090204-7xbi.html

[6] MCOT. Andaman travel fair reflects positive tourism recovery in the region, 2009, http://enews.mcot.net/view.php?id=13146 
[7] C9 Hotelworks. Phuket 2009 Hotel Market Update, 2010, http://www.deliveringcommunications.com/campaigns/c9/docs/C9-PhuketHotel-Update-Jan2010.pdf

[8] Koldowski, J. Tourism Thailand: Going for Quality or Quantity?, February, 2009.

[9] Augustine, N. Managing the Crisis You Tried to Prevent. Harvard Business Review on Crisis Management, Boston: Harvard Business School Press. 1$31,2000$.

[10] Faulkner, B. Towards a Framework for Tourism Disaster Management. Tourism Management, Vol. 22, No. 2, 135-147, 2001.

[11] PATA. Pacific Asia Travel Association. Crisis: It Won't Happen to Us. Bangkok: Pacific Asia Travel Association, 2003.

[12] Ruff, P., and Aziz, K. Managing Communications in a Crisis. England: Gower Publishing Limited, 2003.

[13] UNWTO. United Nations World Tourism Organization. Crisis Guidelines for the Tourism Industry, 2003, http://www.worldtourism.org/market_research/recovery/Crisis\%20and\%20Disaster\%20Mana gement $\% 20$ Guidelines.pdf\#search $=\% 22 \% 22$ Crisis $\% 20$ Guidelines $\% 20$ for $\%$ 20the $\% 20$ Tourism $\% 20$ Industry $\% 22 \% 20$ wto $\% 22$

[14] Aktas, G., and Gunlu, E. Crisis Management in Tourist Destinations. In W. Theobald (ed.), Global Tourism, New York: Elsevier Inc., 3rd ed., 440-455, 2005.

[15] Henderson, J. Tourism Crises: Causes, Consequences, and Management. Oxford: Butterworth-Heinemann, 2007.

[16] Mantanarat, R. TAT sells Phuket Great Time, April, 2011, http://www.ttrweekly.com/site/2011/04/tat-sells-phuket-great-time/

[17] Kaenkrachang, P. Phuket the Most Expensive Place to Live, 2010, http://phuketwan.com/jobs/phuket-expensive-place-live-work-13364/

[18] Khamlo, A. Phuket Tourism: Has Phuket been ruined by tourism?, 2011, http://www.phuketgazette.net/archives/phuketlifestyle/2011/article9934.ht $\underline{\mathrm{ml}}$

[19] Thai Websites. Thailand: Tourist Arrivals from 1998 till 2010. Quarterly Data 2007-2010, 2011. http://www.thaiwebsites.com/tourism.asp

[20] Ketter, E. Marketing in times of financial crisis: Tourism recovery strategies for turbulent times, 2009, http://www.travelvideo.tv/news/travelindustry-info/06-03-2009/marketing-in-times-of-financial-crisis-tourismrecovery-strategies-for-turbulent-times

[21] Beirman, D. A Strategic Approach for the Global Tourism Industry to Overcome the Global Economic Crisis: A 10-Point Plan for Tourism Recovery, 2011, http://www.destinationworld.info/newsletter/ feature60.html

[22] The Phuket News. TAT looks to counter low season lull, 2011, http://www.thephuketnews.com/wp-post.php?id=24664

[23] Phuket News. Phuket hosted seminar "Tourism \& Business in Phuket: Risk \& Challenges from Climate Change”, October $7^{\text {th }}, 2010$, 
http://phuketnews.phuketindex.com/environment/phuket-climate-change180997.html

[24] Gamez, A. and Angeles, M. Borders within. Tourism growth, migration and regional polarization in Baja California Sur (Mexico), Journal of Borderland Studies, Vol. 25, No. 1, ABS Association, USA, 1-18, 2010.

[25] Angeles and Gamez, 2008. Globalización y desarrollo regional, el caso del sector turismo en Baja California Sur, In Ivanova, A and Guillen, A. (Coords.), Globalización y regionalismo: economía y sustentabilidad, México, DF: Porrúa 463-484, 2008.

[26] La Jornada. Cae ocupación hotelera en Los Cabos a 20 por ciento, Thursday, May 14th, Mexico, 2009, http://www.jornada.unam.mx/ 2009/05/14/index.php?section $=$ estados\&article $=036$ n1est. 